\title{
Whether Tax Preference Promotes Innovation in Enterprises?
}

\author{
Zhenguang Huang \\ School of Economy, Jinan University, Guangzhou, China \\ Email: hzg178@gmail.com
}

How to cite this paper: Huang, Z.G. (2019) Whether Tax Preference Promotes Innovation in Enterprises? Modern Economy, 10, 371-385.

https://doi.org/10.4236/me.2019.102025

Received: January 10, 2019

Accepted: January 28, 2019

Published: January 31, 2019

Copyright ( 2019 by author(s) and Scientific Research Publishing Inc. This work is licensed under the Creative Commons Attribution International License (CC BY 4.0).

http://creativecommons.org/licenses/by/4.0/

\begin{abstract}
This paper firstly analyzes the impact and mechanism of tax incentives on corporate financing, innovation investment and innovation output. Secondly, 1311 observations were selected from A-share listed companies as samples, and the propensity score matching method was used to empirically test the net effect of tax incentives on enterprise innovation. Thirdly, it uses linear regression model to analyze the factors affecting the level of innovation of enterprises. The results show that tax incentives have no significant effect on corporate financing and innovation output, but they have a significant role in promoting corporate innovation investment. And the scope of current policy is accurate and efficient. If the preferential treatment spreads to more enterprises, it can also promote its innovation investment to a certain extent, but the average promotion efficiency of preferential policies will be significantly reduced. Finally, it proposes policy recommendations to promote the innovation vitality of enterprises from the aspects of stimulating external innovation investment, perfecting personnel training preferential policies and tracking and evaluation of policies later.
\end{abstract}

\section{Keywords}

Tax incentives, Corporate Innovation, Propensity Score Matching, Linear Regression

\section{Introduction}

In recent years, China's demographic dividend has gradually disappeared with the aging of the population, and investment has also been constrained by problems such as overcapacity. The driving force of labor and capital factor investment on economic growth has declined. The economic growth rate continued to decline from $7.9 \%$ in 2012 to $6.7 \%$ in 2016 [1], and the economy continued to 
exert downward pressure. In order to achieve sustainable and rapid economic development, China urgently needs to improve the contribution of total factor productivity to economic growth through innovation, and enterprises are the main body of innovation activities. The key to improving total factor productivity lies in stimulating the innovation vitality of enterprises and improving the investment, innovation output and management innovation level of enterprise innovation. However, the high risk of corporate innovation activities and the positive spillover characteristics of innovation results lead to insufficient innovation motivation of the enterprise, and market competition cannot make the innovation activities reach the optimal state. It provides a theoretical basis for government intervention and guiding enterprises to carry out innovation activities. Financial subsidies and tax incentives are the two most commonly used measures to stimulate enterprise innovation. Compared with financial subsidies, tax incentives have more obvious effects and have the advantages of wide-ranging, non-discriminatory and enterprise-owned decision-making. At the same time, they can allocate scientific and technological resources through the market which can reduce government interference [2] [3]. So, tax incentives are the main way for the government to stimulate the vitality of corporate innovation.

At present, China has initially formed a preferential system with corporate income tax as the main body to stimulate the innovation vitality of enterprises. The policy is concentrated in: the enterprise income tax of high-tech enterprises is levied at a preferential tax rate of $15 \%$, the research and development expenses of enterprises are deducted by $175 \%$, and the income tax of integrated circuits is periodically reduced or exempted. The policies are classified according to the action points, mainly focusing on the financial innovation of technology innovation, talent cultivation, R\&D capital investment, technology transfer, and results transformation. Moreover, the scope and intensity of tax incentives are constantly increasing. In terms of policies, starting from 2018, the income tax of service-oriented technologically advanced service enterprises will be levied at a rate of 15\%. On April 25, 2018, the State Council executive meeting will launch seven more tax reduction measures to encourage "double-creation" activities. In terms of the total amount of tax reductions, in 2015, China supported the "double-creation" activities to reduce taxes and exemptions by more than 300 billion yuan, of which the implementation of high-tech related preferential policies for tax reductions and exemptions exceeded 140 billion yuan [4]. In 2017, the preferential policies for supporting "double-creation" activities were more than 500 billion yuan, of which high-tech enterprises reduced their income tax by $15 \%$, and promoted the software industry, integrated circuit industry development, tax exemption, corporate income tax and other tax cuts of more than 240 billion yuan. The research and development expenses plus deduction policy exceeds 100 billion yuan [5]. In 2018, the tax reduction for high-tech enterprises in the first quarter reached 90.4 billion yuan, a year-on-year increase of $61.4 \%$ [6]. Based on this background, this paper starts from the theory, based on the 
previous research, further summarizes the induction mechanism and explores the transmission mechanism of tax incentives to stimulate technological innovation of enterprises, and opens the black box of tax incentives. Then based on the actual data of the preferential tax policies of listed companies in China, the actual effect of the tax incentives is verified empirically as a test of the effectiveness of China's tax incentives. Finally, we propose corresponding solutions based on the status quo of normal implementation.

The article is organized as follows: First of all, combined with the importance of innovation capability and the characteristics of enterprise technology innovation, it guides the necessity of formulating tax incentives in China. Secondly, by reviewing the relevant researches of scholars in the past, this paper analyzes and summarizes the existing research characteristics and laws of scholars on tax incentive innovation, and then explores the innovation points of this paper. Third, it theoretically analyzes the impact of tax incentives on corporate finance, $R \& D$ investment, and R\&D output. Fourth, combined with the data of domestic listed companies, it empirically tests the effect of tax incentives on technological innovation of enterprises. Fifth, it analyzes and interprets the empirical results. Sixth, based on the previous research, it puts forward the policy recommendations for improving tax incentives to stimulate technological innovation of enterprises.

\section{Literature Review}

Scholars' research on tax incentives for enterprise innovation can be divided into the following three aspects: Firstly, theoretical research on improving tax incentives: this is mainly to analyze the characteristics and shortcomings of China's tax incentives, as well as the analysis and reference of science and technology tax policies in developed countries such as Japan, America and Germany [7]. Secondly, analyzing the function mechanism of tax incentive for enterprise innovation: although the analysis process and description are different, the views are similar. It is believed that tax incentives encourage enterprises to carry out innovative activities mainly by reducing costs, sharing risks, increasing expected returns and solving liquidity [2] [8]. Thirdly, empirical research on the effects of tax incentives: but there are major differences in empirical methods, variable measures, and conclusions. In the empirical method, the multi-linear regression model is mainly used in the early stage. The tax incentives are used to calculate the elasticity of tax incentives for technological innovation [2] [9] [10]. In the later stage, the propensity score matching method was mainly used. Through the matching of the propensity scores, the experimental group and the control group were constructed, and the average effect of tax incentives on enterprise innovation was measured by the difference of the innovation effects of the two groups [11] [12] [13]. In terms of variable measurement, most of the measurement of tax incentives only pays attention to corporate income tax concessions. The calculation method mainly depends on the difference between the nominal income tax rate and the actual income tax rate multiplied by the total profit [3] [14] [15] and the $\mathrm{B}$ index indicating the actual tax cost per unit of R\&D expenditure [2] 
[16]. The measurement of enterprise innovation includes research and development expenditures on R\&D inputs [2] [3] [16] and the number of patents for innovation output [13] [15] two kinds. There are two kinds of differences between the effective and the invalid. On the one hand, some authors found that tax incentives promoted enterprise innovation investment or innovation output to varying degrees [2] [3] [10] [11], on the other hand, some authors found that the effect of tax incentives for innovation investment or innovation output is not significant [15] [16] [17] [18].

In summary, although scholars have a lot of research on tax incentives to stimulate enterprise innovation, the research perspective is limited, mainly focusing on the end effect of innovation input or output, and less on the effect of tax incentives on innovation input and output. The impact on the source of funding for innovation is also rarely addressed. As for the measurement of tax incentives, since China has not announced the current world-recognized B-index of tax incentives, most domestic scholars use the results of Dai Chen's calculation in 2008, because the actual tax rate is compensated for the loss of the previous period and the deferred income tax. The impact of non-tax incentives does not accurately reflect whether companies enjoy tax incentives.

Therefore, this paper first classifies the tax preferential policies according to the action links, theoretically analyzes the transmission mechanism of tax incentives to stimulate technological innovation of enterprises, and then uses high-tech enterprises with high recognition as the experimental group, and simultaneously uses propensity score matching and multiple linear regression to empirically test the incentive effect of tax incentives on enterprise innovation. Possible innovations in this paper: First, the use of propensity score matching and multiple linear regression to avoid the contingency of a single method leads to empirical results with high stability. Second, according to the characteristics of high-tech enterprises enjoying tax incentives and high recognition, this paper regards high-tech enterprise certification as a measure of enjoying innovative tax incentives, and accurately distinguishes experimental and control samples. Third, according to the focus of tax incentives, we will study the impact of tax incentives on corporate finance, innovation investment ( $R \& D$ personnel and capital) and innovation output (patent application).

\section{The Mechanism of Taxation Promotion Promoting Enterprise Innovation}

\subsection{Promote Corporate Finance}

Funding is the blood of enterprise innovation, and it is also the basis for cultivating innovative personnel and purchasing innovative equipment. Therefore, sufficient funds are the premise of enterprise innovation activities. First, due to the guiding role of fiscal policy, tax incentives will drive social funds into the innovation market. Secondly, from the information asymmetry and the "rational economic man" theory, it is known that financial institutions or venture investors 
who are in the weak position of information give enterprises a limited amount of investment in innovative projects. And if enterprises enjoy innovative tax incentives, on the one hand, they can effectively reduce the risk of innovation activities. On the other hand, enterprises themselves will release positive signals because they receive government approval, which will reduce the difficulty of financing. Furthermore, the tax incentives that give investors the taxable income can promote venture capital by reducing the investment risk of investors. Therefore, innovative enterprises that enjoy tax benefits in theory are more able to finance than innovative companies that do not enjoy tax incentives.

\subsection{Promote Innovation Investment}

Although the tax incentives that encourage enterprises to invest in technological innovation can reduce innovation costs, increase expected returns, and reduce innovation risks, the impact on innovation costs is its main impact [19]. This paper focuses on the pre-tax deduction of research and development expenses (including additional deductions) and the preferential tax rate policy of corporate income tax, and analyzes the mechanism of its incentives for innovation investment.

This paper analyzes the influence of pre-tax deduction on the innovation cost of enterprises by the standard cost model proposed by Jorgenson [20]. Equation (1) means that when there is no tax, the enterprise's innovation input cost. Equation (2) means that when the government collects income tax, the enterprise's innovation input cost. Equation (3) means that when the government gives the tax deduction, the enterprise's innovation input cost. Equation (4) indicates the reduction of the enterprise innovation cost after the tax preference is given. Because the value of Equation (4) is constant positive, tax preference reduces the cost of enterprise innovation.

$$
\begin{gathered}
c=q(r+d) \\
c_{1}=q(r+d) /(1-u) \\
c_{2}=q(r+d)(1-u z) /(1-u) \\
\Delta c=\left(c_{1}-c_{2}\right)=q u z(r+d) /(1-u)
\end{gathered}
$$

From Equation (1) to (4), c indicates the cost of innovative capital when there is no tax, $q, r, d$ respectively indicate capital price, bank interest rate and capital depreciation rate, and all are greater than $0, c_{1}$ indicates the collection of income tax rate of $u$ when the innovative capital cost, $u \in(0,1), c_{2}$ indicates the cost of innovative capital when the government gives $z$ as the pre-tax deduction of benefits, $\Delta c$ indicates the cost of enterprise innovation input after the preferential treatment.

As the cost of innovation declines, enterprises in pursuit of maximizing benefits will increase the investment of innovative capital, until the marginal income of enterprise innovation equals the marginal cost of new innovation. Or from the point of view of correcting the positive externalities of enterprise innovation 
from tax incentives, as shown in Figure 1: $b_{1}$ indicates that when there is no tax preference, the marginal private cost of enterprise innovation. $b_{2}$ is the marginal private cost of enterprise innovation when enjoying tax benefits. MPB is the marginal private income of enterprise innovation. MEB is the marginal external income of enterprise innovation. MSB (MPB + MEB) is marginal social income. When there is no tax incentive, the enterprise decides that the technological innovation investment is $I$ at the point of satisfying $\mathrm{b}_{1}=$ MPB. When tax incentives reduce the marginal private cost of corporate tax in the form of indirect subsidies, $b_{1}$ drops to $b_{2}$, and the investment in technological innovation of enterprises increases from I to the optimal social input level $I_{0}$.

\subsection{Promote Innovation Output}

Further, this paper analyzes the incentive effect of innovative tax incentives on innovation output. On the one hand, China's enterprise innovation is limited by the shortage of funds and poor financing channels [21], according to the Cobb Douglas production function, the output of innovation will follow the level of $\mathrm{R} \& \mathrm{D}$ funds and the number of R\&D personnel increasing. Authors also used empirical analysis to confirm that the $\mathrm{R} \& \mathrm{D}$ expenditures are highly correlated with patent output [22] [23]. On the other hand, the technology transfer exemption of income tax, technology transfer related information services exempt from value-added tax, the conversion of results to give scientific and technical personnel tax incentives and other tax incentives for the output side can directly increase the expected income of enterprises or individuals, and stimulate enterprise innovation output.

\section{Empirical Research on Incentive Effect}

\subsection{Introduction to Empirical Methods}

The propensity score matching method was first proposed by Rosenbaum and Rubin [24]. The basic logic is to first define the processing variables (policy

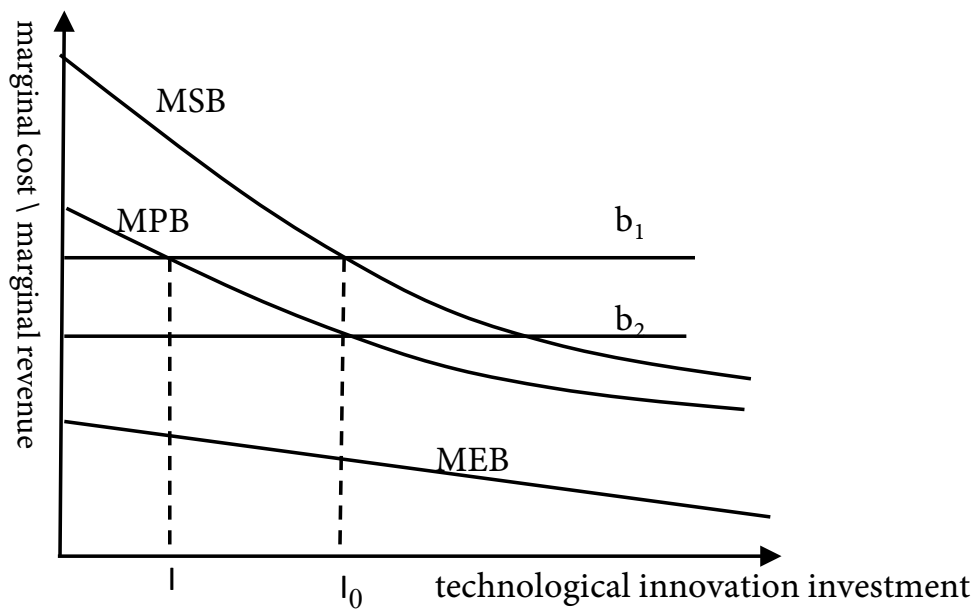

Figure 1. Tax incentives correct the positive externality of technological innovation in enterprises. 
measures), the outcome variables (policy effects), and a set of covariates that affect the results of the sample selection process, and estimate the probability (propensity score) of the sample being processed by covariates; then the experimental group was matched with the control group according to the propensity score value; finally, the mean value difference between the experimental group and the control group was calculated as the average treatment effect.

\subsection{Variable Metric}

\subsubsection{Processing Variable}

Since the propensity score matching method is a binary evaluation method, it is only necessary to find a variable that distinguishes whether the enterprise obtains a discount to divide the experimental group and the control group. At present, China's high-tech enterprises enjoy tax revenues close to half of the national preferential amount, which is the main target of tax incentives for technological innovation, and high-tech enterprises have high recognition. Therefore, this paper regards high-tech enterprises as experimental groups and non-high-tech enterprises as controls group. In the linear regression model, the number of holding companies that have obtained high-tech enterprise certification by the same listed company is an independent variable.

\subsubsection{Result Variable}

This paper measures the effects of tax incentive from three aspects of enterprise financing, innovation investment and innovation output. According to the research content of this paper and the existing literature on the above indicators measurement method [14] [16], we measure Corporate Finance (BC) by "(short-term loan + long-term loan)/total assets". Enterprise R\&D costs (RD) and scientific and technological personnel ratio (RDP) are used to measure enterprise innovation investment; Using the number of patent applications (patent) to measure the innovation output of enterprises.

\subsubsection{Covariances}

Combining with the identification standard of "high-tech enterprise identification management measures" in 2008 and the research needs of this paper, the following indexes affecting the level of enterprise innovation are selected as covariance: Firstly, Enterprise Size (size): The Schumpeter's hypothesis holds that the larger the size of an enterprise, the more efficient its technological innovation is. Moreover, in general, the larger the scale of enterprises, the stronger the ability to resist risks, the more perfect the construction of innovative activities; Secondly, the Age of the enterprise: usually enterprises have different enterprise goals in different cycle stages, the start-up period, the development period of enterprises need to obtain market share through a large number of innovative products and $R \& D$ investment. Because the mature enterprise has the stable market share, the innovation motive force and the $R \& D$ investment is limited; Thirdly, the Enterprise equity concentration (focus): The agency theory holds that the concentration of equity is conducive to reducing the pressure of managers' 
short-term performance, but to the realization of long-term goals; Fourth, asset-liability ratio (DAR): Enterprises with low asset-liability ratios have a stronger ability to resist risks and more resources for innovation activities; Fifth, fast-moving assets (Cash): Enterprises with more fast-moving assets, with less capital turnover pressure, more capital can be used for R\&D Innovation investment; In addition, there is a measure of the use of long-term capital to create profitability of long-term capital return (Rol). Due to China's east, Central and Western economic development is uneven, there are natural differences in innovation levels in different industries and selected industries (industry) and Region (zone) grouping variables.

The model variables are summarized as shown in Table 1.

\subsection{Sample Selection and Data Processing}

Considering the availability and authenticity of the data, this paper selects observations based on the 2015 relevant data published by A-share listed companies. Considering the characteristics of innovation activities, this paper excludes financial enterprises. In order to make the data more stable and representative, this paper excludes the following data: the data is missing; there are special treatment records between 2013 and 2017; the establishment time is zero; the research and development funds are not zero but the research and development personnel are zero. Finally, a sample consisting of 1311 observations was obtained, of which 508 observations in the experimental group and 731 observations in the control group. The data was taken from CNINF and CSMAR.

\section{Empirical Results and Analysis}

\subsection{Calculate the Average Processing Net Effect}

Four propensity score matching models were established based on the enterprise financing level, R\&D funds, R\&D personnel, and patent applications. In order to obtain more stable results, each model is matched by four matching methods: probability ratio, k-nearest neighbor, radius matching and kernel matching. The processing effects of the four models in different matching methods are shown in Table 2: the average treatment effect on treatment group (ATT) indicates that the difference between the current preferential enterprises and the non-preferential enterprises, the average treatment effect on untreated group (ATU) indicates that if the current is not received by preferential enterprises after the change value, the average treatment effect on population (ATE) represents the average preferential effect of the sample. Model (1) and model (2) obtained significant positive ATT values at $1 \%$ or $5 \%$ under each matching method, indicating that the current innovative tax incentives have a significant effect on promoting R\&D funds and personnel investment. Except for model (2), the ATU is smaller than ATT in radius matching, ATU is less than ATT, and only part of ATU is significant, and ATE is significantly positive in each matching method, indicating that the current tax preferential policy is applicable 
Table 1. Variable summary table

\begin{tabular}{|c|c|c|}
\hline Variable type & Variable name (symbol) & Variable definitions \\
\hline independent & Tax incentives 1 (Treat) & high-tech enterprises: Treat $=1$, non-high-tech enterprises: Treat $=0$ \\
\hline \multirow[t]{2}{*}{ variable } & Tax incentives 2 (DTreat) & $\begin{array}{l}\text { The number of holding companies that obtain the certification of high-tech enterprises } \\
\text { with the same listed company }\end{array}$ \\
\hline & Corporate finance (BC) & (short-term loan + long-term loan)/total assets \\
\hline \multirow{7}{*}{$\begin{array}{l}\text { dependent } \\
\text { variable }\end{array}$} & Enterprise R\&D costs $(\mathrm{RD})$ & Enterprise $\mathrm{R} \& \mathrm{D}$ costs $(\mathrm{RD})$ \\
\hline & Enterprise R\&D personnel (RDP) & Enterprise R\&D personnel (RDP) \\
\hline & Innovation output (Patent) & The total number of patent applications filed by the company for the applicant \\
\hline & Business scale (Size) & $\log ($ Total assets of the enterprise) \\
\hline & Business age (Age) & 2015-year of establishment \\
\hline & Equity concentration (Focus) & $\log$ (The sum of the shareholding ratio of the top three shareholders) \\
\hline & Gearing ratio (Dar) & Total liabilities/Total assets \\
\hline \multirow[t]{4}{*}{ covariance } & Quick-moving assets(Cash) & $\log ($ Monetary fund + receivables + trading financial assets $)$ \\
\hline & Long-term return on capital (Rol) & (net profit + income tax expense + financial expenses)/Long-term capital \\
\hline & Industry (Industry) & $\begin{array}{l}\text { Manufacturing: } \text { manu }=1 \text {, or manu }=0 \text {, Information technology industry: tech }=1 \text {, or } \\
\text { tech }=0 \text {, Based on other industries. }\end{array}$ \\
\hline & Zone (Zone) & $\begin{array}{l}\text { Registered in the east: east }=1 \text {, or east }=0 \text {, Central: } \operatorname{mid}=1 \text {, or } \operatorname{mid}=0 \text {, Based on other } \\
\text { industries Western. }\end{array}$ \\
\hline
\end{tabular}

Table 2. Average processing net effect of preferential policies.

\begin{tabular}{|c|c|c|c|c|c|}
\hline Matching methods & Processing effect & $\begin{array}{c}\text { Model (1) } \\
\text { RD }\end{array}$ & $\begin{array}{l}\text { Model (2) } \\
\text { RDP }\end{array}$ & $\begin{array}{c}\text { Model (3) } \\
\text { BC }\end{array}$ & $\begin{array}{c}\text { Model (4) } \\
\text { Patent }\end{array}$ \\
\hline \multirow{3}{*}{ probability ratio } & ATT & $\begin{array}{c}0.120^{* * *} \\
(2.87)\end{array}$ & $\begin{array}{l}0.220^{* *} \\
(2.53)\end{array}$ & $\begin{array}{l}0.003 \\
(0.34)\end{array}$ & $\begin{array}{l}0.098 \\
(0.84)\end{array}$ \\
\hline & ATU & $\begin{array}{c}0.080^{* *} \\
(1.83)\end{array}$ & $\begin{array}{l}0.146 \\
(1.55)\end{array}$ & $\begin{array}{l}0.012 \\
(1.20)\end{array}$ & $\begin{array}{l}-0.141 \\
(-1.23)\end{array}$ \\
\hline & ATE & $\begin{array}{c}0.098^{* * *} \\
(3.05)\end{array}$ & $\begin{array}{c}0.179^{\star *} \\
(2.51)\end{array}$ & $\begin{array}{l}0.008 \\
(1.14)\end{array}$ & $\begin{array}{l}-0.035 \\
(-0.39)\end{array}$ \\
\hline \multirow{3}{*}{$\begin{array}{c}\text { K-near neighbor } \\
\quad(\mathrm{k}=1)\end{array}$} & ATT & $\begin{array}{c}0.120^{* * *} \\
(2.96)\end{array}$ & $\begin{array}{c}0.220^{* *} \\
(2.53)\end{array}$ & $\begin{array}{l}0.003 \\
(0.37)\end{array}$ & $\begin{array}{l}0.098 \\
(0.84)\end{array}$ \\
\hline & ATU & $\begin{array}{l}0.080^{\star} \\
(1.65)\end{array}$ & $\begin{array}{l}0.146 \\
(1.61)\end{array}$ & $\begin{array}{l}0.0112 \\
(1.16)\end{array}$ & $\begin{array}{l}-0.141 \\
(-1.19)\end{array}$ \\
\hline & ATE & $\begin{array}{c}0.098^{* * *} \\
(2.82)\end{array}$ & $\begin{array}{c}0.179^{* * *} \\
(2.66)\end{array}$ & $\begin{array}{l}0.008 \\
(1.11)\end{array}$ & $\begin{array}{l}-0.035 \\
(-0.38)\end{array}$ \\
\hline \multirow{3}{*}{$\begin{array}{l}\text { Radius matching } \\
\qquad(\mathrm{r}=0.01)\end{array}$} & ATT & $\begin{array}{c}0.104^{\star * *} \\
(4.48)\end{array}$ & $\begin{array}{c}0.195^{* * *} \\
(3.51)\end{array}$ & $\begin{array}{l}0.006 \\
(1.17)\end{array}$ & $\begin{array}{l}0.065 \\
(0.88)\end{array}$ \\
\hline & ATU & $\begin{array}{c}0.123^{\star * *} \\
(3.91)\end{array}$ & $\begin{array}{c}0.206^{* * *} \\
(2.85)\end{array}$ & $\begin{array}{l}0.008 \\
(0.12)\end{array}$ & $\begin{array}{l}-0.008 \\
(-0.08)\end{array}$ \\
\hline & ATE & $\begin{array}{c}0.115^{* * *} \\
(4.56)\end{array}$ & $\begin{array}{c}0.202^{\star * *} \\
(3.39)\end{array}$ & $\begin{array}{l}0.003 \\
(0.57)\end{array}$ & $\begin{array}{l}0.025 \\
(0.33)\end{array}$ \\
\hline \multirow{3}{*}{ Kernel matching } & ATT & $\begin{array}{c}0.120^{* * *} \\
(2.85)\end{array}$ & $\begin{array}{c}0.220^{* * *} \\
(2.61)\end{array}$ & $\begin{array}{l}0.028 \\
(0.35)\end{array}$ & $\begin{array}{l}0.098 \\
(0.88)\end{array}$ \\
\hline & ATU & $\begin{array}{l}0.080^{*} \\
(1.75)\end{array}$ & $\begin{array}{l}0.146 \\
(1.60)\end{array}$ & $\begin{array}{c}0.12 \\
(1.21)\end{array}$ & $\begin{array}{l}-0.141 \\
(-1.17)\end{array}$ \\
\hline & ATE & $\begin{array}{c}0.098^{* * *} \\
(2.98)\end{array}$ & $\begin{array}{c}0.179^{\star * *} \\
(2.59)\end{array}$ & $\begin{array}{l}0.008 \\
(1.13)\end{array}$ & $\begin{array}{l}-0.035 \\
(-0.39)\end{array}$ \\
\hline
\end{tabular}

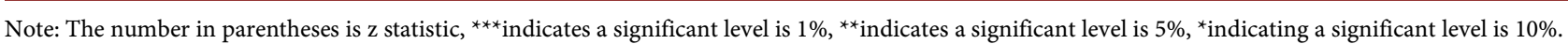


accurately and efficiently. If the preferential treatment is spread to more enterprises, it can also promote its innovation investment to a certain extent, but the average promotion efficiency of preferential policies will be significantly reduced. The results of model (3) and model (4) show that the effect of innovation tax incentives on promoting corporate finance and innovation output is small and not significant.

\subsection{Model Checking}

In order to test the robustness of the model, the balance test was performed on the data after the odds ratio matching. The results showed that 577 of the 580 experimental group observations were successfully matched, and 3 were not successfully matched. Among the 731 control group observations, there were 718 successful matches and 13 failed to match. That is, most of the samples are in the matching common interval, and the sample loss is less after matching. In addition, the standardized deviation test before and after the matching of each variable is shown in Table 3: Except for the Focus and Manu variables, the standardization deviations of each variable are greatly reduced, and most of them are reduced to the level below $5 \%$, that is, the balance test shows that the sample is ideally modeled by the tendency matching score method.

\subsection{Further Research}

Since the propensity score matching method is a binary processing method, it can only analyze the processing effect of the tax preferential policy. In order to further analyze the impact of each covariate on the level of innovation of enterprises, we take the number of enterprises in the sample experimental group obtained by high-tech enterprises as the independent variable (DTreat), each covariate as the control variable, and the $\mathrm{R} \& \mathrm{D}$ funding and $\mathrm{R} \& \mathrm{D}$ personnel as the resulting variables to establish linear regression models (5) and (6).

The regression results of the model are shown in Table $4: \mathrm{R}^{2}$ of the two models are 0.455 and 0.402 , respectively, indicating that the model is highly resolved; except for the long-term return on capital (Rol) and the company size (Size) of model (6), other variables are significant. It indicates that the model variables are selected reasonably and the analytical ability is strong. The DTreat regression coefficient is positive and significant at the $1 \%$ level, indicating that the linear regression method also proves that tax incentives significantly promote corporate $\mathrm{R} \& \mathrm{D}$ funding and personnel input. From the perspective of the industry, research and development funds and personnel investment in the information technology industry, traditional manufacturing industries, and other industries have been reduced in turn. From the perspective of the region, from the east to the west, the company's research and development funds and personnel investment have also decreased. In addition, the more quick-moving funds and the higher the return on long-term capital, the more $\mathrm{R} \& \mathrm{D}$ investment the enterprise has, and the longer the establishment time and the higher the asset-liability ratio, 
Table 3. Standardized deviation of covariance (\%).

\begin{tabular}{ccccccccccc}
\hline & Size & Age & Focus & DAr & Cash & Rol & manu & tech & east & mid \\
\hline $\begin{array}{c}\text { Before } \\
\text { match }\end{array}$ & -47.000 & -23.000 & -9.500 & -29.700 & -43.000 & -2.500 & -0.400 & 10.100 & 24.700 & -4.200 \\
After match & -0.700 & -7.900 & 12.100 & -3.500 & -1.000 & 2.200 & 5.100 & -3.700 & -1.500 & 0.500 \\
Deviation & 98.500 & 65.700 & -27.000 & 88.300 & 97.700 & 10.600 & -1156.100 & 63.700 & 93.800 & 88.800 \\
\hline
\end{tabular}

Table 4. Results of linear regression models.

\begin{tabular}{ccc}
\hline Variables & Model(5) & Model(6) \\
& RD & RDP \\
\hline \multirow{2}{*}{ DTreat } & $0.049^{* * *}$ & $0.102^{* * *}$ \\
& $(-5.69)$ & $(-4.96)$ \\
Size & 0.12 & 0.114 \\
& $(-1.46)$ & $-0.76)$ \\
Age & $-0.068^{* *}$ & $-0.136^{*}$ \\
Focus & $(-2.15)$ & $(-1.81)$ \\
& $-0.098^{* *}$ & $-0.201^{* *}$ \\
DAr & $(-2.54)$ & $(-2.52)$ \\
& $-0.256^{* * *}$ & $-0.403^{* *}$ \\
Cash & $(-2.69)$ & $(-2.20)$ \\
& $0.702^{* * *}$ & $1.441^{* * *}$ \\
Rol & -10.89 & $(-10.24)$ \\
& $0.211^{* *}$ & -0.01 \\
manu & $(-2.36)$ & $(-0.04)$ \\
& $0.178^{* * *}$ & $0.214^{* *}$ \\
tech & $(-4.44)$ & $(-2.47)$ \\
& $0.281^{* * *}$ & $0.550^{* * *}$ \\
east & $(-6.56)$ & $(-5.56)$ \\
& $0.220^{* * *}$ & $0.277^{* * *}$ \\
mid & $(-4.97)$ & $(-3.31)$ \\
constant & $0.128^{* *}$ & $0.173^{*}$ \\
R2 & $(-2.36)$ & $(-1.73)$ \\
& 0.468 & $-7.954^{* * *}$ \\
\hline
\end{tabular}

Note: The number in parentheses is T statistics, ${ }^{* * *}$ indicates a significant level at $1 \%,{ }^{* *}$ indicates a significant level at $5 \%$, ${ }^{*}$ indicating a significant level at $10 \%$. Manufacturing and information technology are classified on the basis of other industries, and east and Central are based on the western region.

the less R\&D investment, which is consistent with the analysis results of the covariate selection. The concentration of ownership is negatively related to innovation investment, which may be due to contract incompleteness and information asymmetry. When the interests of managers and shareholders share conflicts, and the supervision is not in place, managers choose short-term management goals that are beneficial to them [25]. The scale of enterprise has no significant effect on innovation investment, which may be due to the non-linear relationship between enterprise innovation and scale increasing first and then decreasing [26].

\section{Conclusion and Suggestion}

\subsection{Conclusion of the Study}

This paper firstly analyzes the role mechanism of tax incentives to stimulate 
enterprise innovation, and then uses the tendency score matching method to empirically analyze the incentive effect of tax incentives from three aspects: corporate financing, innovation investment and innovation output. The results show that the current innovative tax incentives have no significant effect on the enterprises financing and innovation output, but they have a significant positive incentive effect on the innovation investment, and the scope of the policy is accurate and efficient. If the preferential treatment is spread to more enterprises, it can also promote its innovation investment to a certain extent, but the average promotion efficiency of preferential policies will be significantly reduced. Furthermore, this paper establishes a linear regression model to test the reliability of the results of the propensity score matching model, and analyzes the impact of each covariate on the level of enterprise innovation. The results also prove that the innovation concessions have significantly promoted the innovation investment of enterprises, and the level of innovation input of enterprises in the eastern, central and western regions has decreased significantly, and the level of innovation input in the information technology industry, traditional manufacturing industry and other industries has also decreased significantly. In addition, the more quick-moving funds and the higher the return on long-term capital, the more $R \& D$ investment, and the lower the asset-liability ratio, the less $R \& D$ investment.

\subsection{Suggestions for Improving the Policy}

Firstly, increase the incentives for external innovation investment, and guide the flow of market funds to corporate innovation activities. At present, the funds for innovation activities of listed companies in China mainly come from within the enterprise and the contribution from external finance is limited [27]. However, Chinese enterprises are in a financial system based on indirect financing. Traditional financial institutions, which are the main suppliers of corporate financing funds, tend to focus on physical assets and light intangible assets, which makes innovative companies that enjoyed tax incentives and reduced innovation risks fail to obtain more external financing. It makes the current innovative tax incentives just play a rewarding effect and a monetary effect promoting innovation investment, but failing to give full play to the market guidance role of the policy, and the external financing level of the enterprise is not significantly improved. As a supplement to traditional financial institutions, speculative institutions led by venture capital firms are one of the sources of external financing for corporate innovation activities. Although our country has introduced tax incentives to encourage investment in these enterprises, it is currently only applicable to enterprises which are in the initial stage and the high-tech enterprises that are not listed. Therefore, this paper proposes to further increase the tax incentives for venture capital enterprises and expand the scope of application after summing up the previous experience, in order to broaden the financing channels of enterprises and reduce the difficulty of financing enterprise innovation activities. 
Secondly, it is recommended to implement a preferential training policy for talents at different levels to improve the quality of innovative personnel. On the one hand, the number of senior technicians required for innovation activities is limited. And the large-scale and strong innovation incentives increase the cost of peer competition for senior technicians. On the other hand, although the deduction ratio of employee training expenses has increased from $2.5 \%$ to $8 \%$ since 2018 and it will help the cultivation of technical talents and increase the number of technical talents in enterprises, the current use of staff training fees is relatively wide which may not be able to effectively and rationally allocate training funds. Increasing the number of innovative talents, but it has not effectively improved the quality of talents. As a result, although innovative tax incentives have significantly promoted corporate innovation funds and personnel input, the increase in innovation output is not obvious. It is recommended to establish a more specific policy that is positively related to the R\&D personnel level, and give a higher deduction ratio for the training of senior technicians to cultivate more high-quality innovative talents.

Thirdly, improving the efficiency of tax incentives by strengthening the follow-up and evaluation of tax incentives. On the one hand, in the face of huge tax incentives such as high-tech enterprises, enterprises may falsify materials, adjust the original structure to meet the conditions for high-tech enterprises, or obtain preferential treatment through the false declaration of intermediary agencies. On the other hand, a wide range of tax incentives may be applied to projects with a low marginal productivity, resulting in lower innovation output. It is recommended to increase the review of innovative preferential application materials, and require high-tech enterprises to regularly report to the public the innovative indicators such as research and development expenses, number of researches, development personnel and innovation results. Improving the incentive efficiency of tax incentives for innovation by eliminating false declarations and making tax incentives come true.

\section{Conflicts of Interest}

The authors declare no conflicts of interest regarding the publication of this paper.

\section{References}

[1] National Bureau of Statistics of China. http://data.stats.gov.cn/easyquery.htm? $\mathrm{cn}=\mathrm{C} 01$

[2] Dai, C. and Liu, Y. (2008) A Comparative Analysis of the Impact of Tax Preference and Financial Subsidy on Corporate R\&D. Economic Science, 3, 58-71.

[3] Ma, W.H. (2011) The Empirical Research on Business R\&D Investment by the Means of Tax incentives and Government Subsidies-Based on Panel Data of Listed High-Tech Enterprises. Science \& Technology Progress and Policy, 28, 111-114.

[4] http://money.163.com/16/0128/09/BEDJHB8F00254TI5.html

[5] http://www.chinatax.gov.cn//n840303/c3222235/content.html 
[6] http://www.ctax.org.cn/csyw/201805/t20180503_1075755.shtml

[7] Sun, J.F. and Ma, W.H. (2004) On the Transformation of Tax Preferential Policies for China's High-tech Industry. Public Finance Research, 3, 31-33.

[8] Lou, H.T. and Xu, T.J. (2008) Research of the Influence Mechanism of Tax Incentives on Technological Innovation. R\&D Management, 20, 88-94.

[9] Jiang, J.J. and Qi, J.G. (2007) The Tax Policy Effect for Promoting Enterprises' R\&D Investments. China Soft Science, 8, 65-70, 84.

[10] Wang, X. and Zhang, J.Y. (2015) Evaluation of the Economic Effect of Tax Preference on Enterprise Innovation. Public Finance Research, 1, 58-62.

[11] Ma, Y.Q., Hu, R.P. and Zhao, Y.Y. (2016) Tax Incentive, Financial Subsidy and Innovation Investment of Zhongguancun Enterprises: An Empirical Study Based on Propensity Score Matching Method. Science and Technology Management Research, 36, 1-6.

[12] Shi, S.B., Zhou, G.G. and Qin, L.H. (2017) The Incentive Effect of Tax Incentives on R\&D Investment and Output of Chinese Enterprises. Taxation Research, 3, 43-47.

[13] Zhang, X.D., He, Y.N. and Ma, X.M. (2014) An Analysis of the Incentive Effects of R\&D Preferential Tax Policies on Business Innovative Outputs: A Study Based on the National-Recognized Enterprise Technical Centers. Contemporary Finance \&Economics, 11, 35-45.

[14] Chu, D.Y., Yang, S. and Song, G.M. (2016) Fiscal Subsidies, Tax Incentives and Innovative Investment in Strategic Emerging Industry. Finance and Trade Research, 27, 83-89.

[15] Zheng, C.M. and Li, P. (2015) The Impact of Government Subsidy and Tax Preferential on Enterprise Innovation Performance-An Empirical Study Based on GEM High-tech Enterprises. Science \& Technology Progress and Policy, 32, 83-87.

[16] Yuan, J.G., Fan, W.L. and Cheng, C. (2016) Tax Preference and Technical Innovation of Enterprises: An Empirical Study Based on Chinese Listed Companies. Taxation Research, 10, 28-33.

[17] Jiang, J. (2011) Do Public Policies Support Firm's Innovation? A Comparative Analysis on the Subsidies and Tax Credit. Science Research Management, 32, 1-8 + 50.

[18] Xia, L. (2012) Has Preferential Tax Improved Technological Innovation: A Study Based on Firms Listed on GEM Board. Forum on Science and Technology in China, $12,56-61$.

[19] Wang, J. (2012) Research on the Mechanism and Incentive Effect of Government R\&D Funding. Economic Science Press, Beijing.

[20] Jorgenson, D.W. (1963) Capital Theory and Investment Behavior. The American Economic Review, 53, 247-259.

[21] Jin, H. and Liu, W.J. (2012) Constraints Factors and Path Breaking of Small and Medium High-Tech Enterprises Growth. Science and Technology Management Research, 32, 118-122.

[22] Chen, G.H. and Lan, B.J. (2007) Research on R\&D Spending, Competitiveness, and China's Regional Innovation Ability-On the Basis of Empirical Analysis of Patent Application Number and R\&D Data. Economist, 3, 101-106.

[23] Pang, S.Y. and Chen, D.Z. (2009) A Study on the Relationship between R\&D Inputs and Patents: Panel Data Analysis of Top Global Companies by R\&D Investment. Studies in Science of Science, 27, 1500-1505. 
[24] Rosenbaum, P.R. and Rubin, D.B. (1983) The Central Role of the Propensity Score in Observational Studies for Causal Effects. Biometrika, 70, 41-55.

https://doi.org/10.1093/biomet/70.1.41

[25] Yang, H.J. and Yang, J.J. (2015) Ownership Concentration, Managerial Compensation and Technology Innovation Choices. Science Research Management, 36, 48-55.

[26] Niu, Z.D., Zhang, Q.X. and Wang, W. (2012) Firm Size and Technological Innovation of Chinese High-Tech Industries: An Analysis Based on Panel Smooth Transition Regression Model. Journal of Central University of Finance \& Economics, 10, 68-74.

[27] Ju, X.S. (2013) Sources of Financing and Smoothing Mechanism for Innovative Investment of Listed Companies in China. The Journal of World Economy, 36, 138-159. 